\title{
雑草防除から「理想的」植生管理へ
}

\author{
佐合隆一*
}

キーワード: 雑草防除, 雑草管理, 雑草学, 除草剂

戦後, さまざまな科学技術が急速に進歩するとと もに, 産業構造の変化にともない労働生産性の高い 農業が求められてきた。それらを可能にした革新的な 技術の一つとして除草剤の開発・普及が挙げられる。 また，除草剤を開発・普及する上では「雑草」その ものの情報が不足していたために, 雑草についての試 験研究か広範囲で行われるようになった。すなわち, 除草剂の出現と雑草防除や雑草の生態にかかわる技 術研究がセットとなり,「雑草学」が急速に発展して きた。したがって,「雑草学」は, この50年前後の 比較的歴史の浅い学問分野であるとともに, 欧米の 雑草学会をはじめわか国においても, 除草剤の開発・ 研究や普及と密接にかかわる分野で, 多くの研究者 を輩出してきた。今日，優れた多くの除草剤が普及 し, 農耕地の雑草防除技術があらかた達成されるに 及んで, 雑草学の大きな推進役であった雑草そのも のに対する研究がいさか閉塞状態に陥っていると思 える ${ }^{1)}$ 中で, 改めて「雑草防除」研究のあり方につ いて議論してみることとした。

有史以来，農業生産に扔ける最も過重な労働に 「草取り」があった。また, 「草取り」作業は人力に よる方法や鎌や鍬などの道具を使用して行われ, 耕 耘や中耕作業も雑草防除の手段として重要な役割を 担っており, 水稲栽培では総労働時間の約半分が除 草労働時間となっていた。畑作においては, 雑草の 侵入を阻止するために輪作や混作が行われ，それぞれ の地域に適した作付体系が作り上げられ，ヨーロッパ に扩ける輪作体系がその典型的事例として示されてい る ${ }^{8)}$ 。これらは病害虫と同様に「害草＝雑草」の「駆 除=防除」が最大の関心事であり, その手段として の除草剤が開発されてきた。また, 優れた除草剤の 普及に伴い, 雑草防除を目的とした諸作業の意義が

\footnotetext{
*茨城大学農学部附属フィールドサイエンス教育研究セ ンター テ300-0331 茨城県稲敷郡阿見町阿見 4668-1 sago@mx.ibaraki.ac.jp

(2007年3月9日受付, 2007 年 5 月 6 日受理)
}

見直され，例えば農耕の根源的意義である耕耘から 除草剂使用を前提とした不耕起栽培へ, 長年の作付 け体系（輪作）から商品性の高い作物の連作栽培へ の変化をも可能にしてきた。

\section{1. 雑草の再定義}

雑草の定義についてはさまざまな議論があり，萩本 が今日的課題として提起している1)。ここでは農学的 な立場から雑草が「人間生活に邪魔な植物あるいは 望まないところに生える植物」として定義するとして も，具体的に現在わが国に雑草は何種あるかを定義 ゔけできる人はいない。そのため今日においても，笠 原の調査結果 ${ }^{7)}$ による耕地雑草の種類数が数多く引 用されている。笠原は水田, 水田裏作, 畑作, 樹地 園, 芝生, 林苗圃および沿海地の場面ごとに出現す る種を取上げ, 強害草, 害草, 弱害草に区分し, 駆 除が困難な種を強害草, 畦畔よりも圃内に多く発生 し, 発生数度が強害草より低いものを害草, 圃内に 少し生えるものを畦畔雑草 (弱雑草) と分類してい る。これは笠原が述べているように，1942年当時ま での除草作業により残された雑草のリストであり, 今 日の防除手段で残された防除必要な草種とは異なる ことは当然なことである。1996年から1998年に全国 の27大学で共同研究として実施した「畑地および樹 園地における雑草の生態調査」(2000) 結果 ${ }^{22}$ にお いても, 笠原氏が調査された時期（1942）の草種構 成と現在（1998）の草種構成を比較すると, 著しく 変化してきていることが明らかである（第1図）にも かかわらず, 場面ごとに「防除必要な草種=雑草」と 「必ずしも防除が必要ではない草種」が明確にされな いままに今日に至っている。

\section{2. 雑草は根絶が必要か}

農業生産は雑草との戦いと言われるように, 雑草 防除は農耕地における雑草の根絶が目標とされてき た。すなわち, 人力除草の大原則として「草のいまだ 見えざるに中うちし芸ぎる」(貝原益軒) とあり, 雑 草は出芽前後の根絶が重要である。また, 除草剤に 
よる防除の場合も, 水田や畑作・野菜畑での雑草は 作物と競合して，作物の生育収量に影響を与えるこ とから，競合する期間 (critical weed free period) は減収をさけるために根絶をはかる必要があることが 科学的に実証されてきた。一方, 草生管理の果樹園, 畦畔や畑地周辺などの緑地において「杂隹草」と総称 されている植物の中には「薬用植物」「観賞用植物」 「食用となる植物」などが含まれており, 農作業上や 農業生産上「害」となる植物との間が明確とされな いまま, 一括して「雑草」として防除の対象となって いる。しかし, 草生管理の果樹園, 畦畔や畑地周辺 の緑地は，裸地化が必ずしも望ましいことではなく， 緑地としての維持を考える場合には,「雑草」を必ず しも根絶する必要がない。また, 水田や畑作・野菜 畑においても, 休閑期の裸地化を避ける植生管理も 検討されるべき課題である。

\section{3. 理想的植生}

従来あいまいな表現で定義付けられている雑草種
の中で防除を必要とする「真の雑草は何か」,「人里 域から農耕地分野ごとの理想的な植生管理法とは何 か, 「主要雑草の管理方法 (耕種, 機械, 除草剂種 類別）ごとの雑草の生態反応」を明確にして, 雑草 の防除ではなく植生 (雑草) 管理することが必要で ある。すなわち, 樹園地および農耕地周辺の緑地は 雑草の根絶を図ることではなく, 雑草の種構成を考 慮した上で，より容易な（理想的な）植生へ誘導す る管理手法の確立が重要である。具体的には, 作物 と競合する期間は裸地化することか理想的植生であ り, 農耕地周辺の緑地では景観形成の面や種の多様 性など多面的な便益を考慮しながら，例えば在来草 種のうち人類にとって害がない草種であり, 誰が見て も花のきれいな小型草種を存続させる植生も理想的 植生である。前中 (9) は「従来の雑草は市街地におい ても雑草か?」と問いかけており，ランドスケープに 関連して人間が植物に求めている役割には，1）植 物が存在することで生じる機能，2）景観・緑環境の 形成要素,3）文化財, 生活のアメニティ要素, 4)

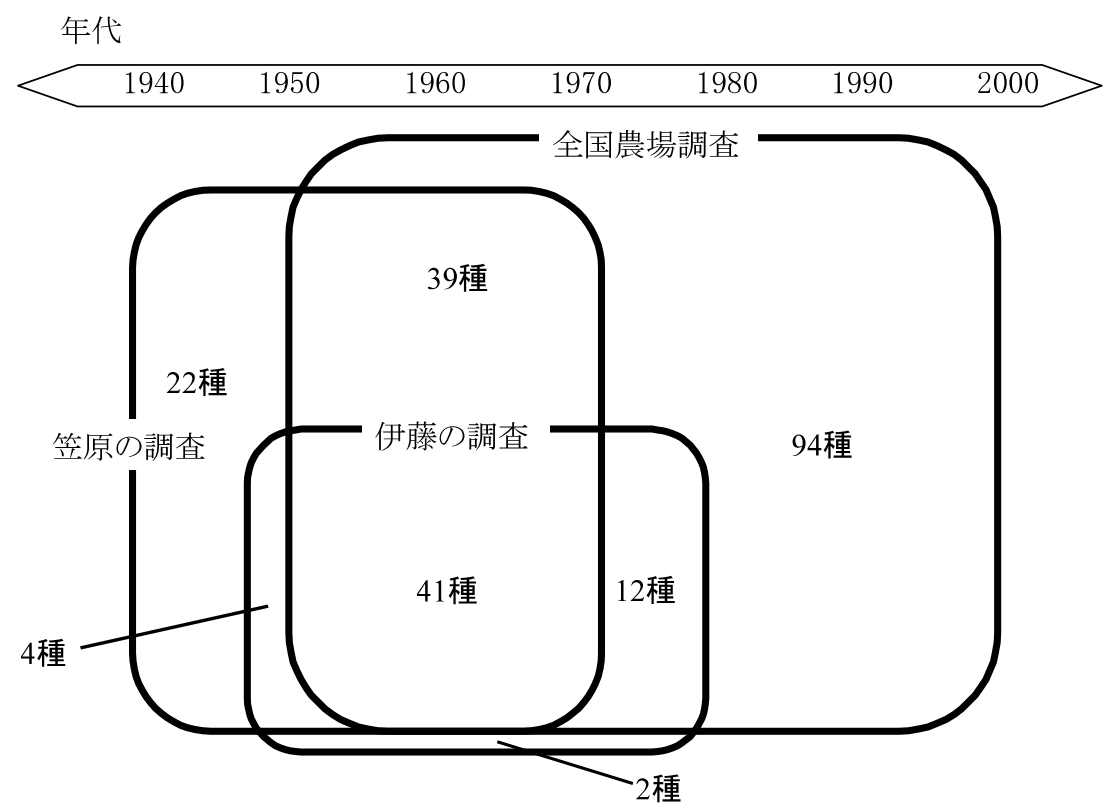

第1図＼cjkstart樹園地における異なる調査時期間での出現雑草の関係

調査結果は下記文献を参照した。

笠原：笠原安夫「日本雑草図説」1972. 養賢堂, 東京.

伊藤：伊藤幹二 1974. 果樹園における雑草の生態と調節に関する研究, 京都大学博士論文.

全国農場：塩谷哲夫 ·佐合隆一ほか 2000. わが国における畑地および樹園地雑草の種類と優占草種の変化, 農作 業研究 35(別 1), 15-16. 
生物的自然要素を挙げている。すなわち, 場面ごと に理想とする植生があり，これらを具体的に管理でき る手法を明らかにすることが必要である。

\section{4. 植生の遷移と雑草防除法}

わが国では裸地化した土地を管理せずに放置する と,さまざまな植物が出現する。出現種は埋土種子 の構成, 裸地化の時期や立地によって異なるが, 年 次を経るにしたがって, 生活型でみると, 一年生草本 $\rightarrow$ 越年生草本 $\rightarrow$ 多年生草本 $\rightarrow$ 木本への遷移がみられ ることが知られている。私たちの調査においても埋立 地校庭 ${ }^{3)}$, 野菜畑地跡や都市部の孤立林内 ${ }^{4)}$ で, 裸 地後数年で木本種が侵入し定着することを確認して いる5)。いわゆる里山域から農耕地の植生を管理せず に放置することは，二次遷移によって数年で木本が 侵入する群落となることから, 草本群落を維持する には，人類による意図的な管理が欠かせないことは言 うまでもないことである。

また，わか国の暖温带から冷温带における草地は， 森林の発達が許容される地に人為的な原因によって 成立維持されているので, 放置しておけば木本群落 へ向かって遷移が進行する。半自然草地は数年から 一年の刚払いでススキ型草地が維持されるのに対して 連続的な放牧下ではシバ型草地が維持されることが 知られている ${ }^{11)}$ 。水田畦畔においても, 刈払いの頻度 が高くなるとシバ草地となり刚払い頻度の低下に応じ てチガヤ，ススキが優占化する6。 。また，同じ刚払い 頻度でも多年生草本種が多い伝統的畦畔では種の多 様性が維持できるが，基盤整備後の年数が少ない畦 畔では一年生草本種が多いため, 刈払い頻度が高く なるとギャップが多く発生し, 種多様度か泜下するこ とが明らかとなっている。。このように刈払い頻度に よって形成される群落が異なることから, 理想的植生 を維持するためには，1）裸地化後からの年数に応じ た刈払い方法の検討，2）過重な刚払い労力の確保お よび3）刈払いに代替する管理方法なと検討すべき課 題が多い。

さらに，刚払い作業に代わりうる管理手段として 除草剂散布が考えられる。しかし, 農耕地内では, 除 草剂の体系使用や各種混合製剂の除草剂か開発され, 省力的で合理的な除草剤の使用方法が確立してきて いるが, 農耕地周辺や草生果樹園の場面では, 非選 択性茎葉処理除草剂の連用が主流 ${ }^{14)}$ となっており, 植生管理の上ではさまざまな問題を抱えている。

\section{5. 理想的植生への誘導}

これまでは, 雑草防除手段として「引抜き」「刈払 い」「耕耘」「除草剂散布」などの作業が行われ, 作 物との選択を考慮した杂隹草防除が行われてきたが, 雑 草に対しては非選択的に防除してきた。その結果, 「種の多様性」「生態系の貧困化」などの環境保全に かかわる問題が提起されるに及んで，この課題に対応 できないまま今日を迎えている。すなわち，この場面 での雑草管理手段として, 極めて多労を要す機械防 除や，ほとんどの植物を枯殺する非選択性の除草剤 が使用されてきた ${ }^{15)}$ 。その結果，例えば私たちの樹園 地に扔ける1998年調査での草種構成と笠原が調査し た時期（1942）の草種構成を比較すると, 小型で美 観の良い草種が著しく減少し, 見栄えの悪い大型草 種が優占化してきている (第1表) ${ }^{12)}$ 。言い換えると, 場面によっては小型で美観のよい小型草種は防除の 必要がないにもかかわらず，除草剤の使用によってこ れらの草種を滅亡させてきており, 防除の必要な大型 草種か瀿茂するという悪循環になってきている。そも そも「雑草」は人間の経済的活動にマイナスを及ぼ す草本種という考えからすると, 必ずしも「雑草」で はない草種まで「雑草」として扱ってきたのではない だろうか? この反省から立脚すると, いろいろの場 面を想定し，それぞれの場面において「存在しても問 題とならない植物種」が優占化する植生へ管理する ことが本来あるべき雑草管理である。草種によっては ある場面では雑草であるが, ある場面では雑草ではな いというケースもあることが考えられるが，これまで の雑草防除法の連用が人類にとって好まざる植生へ 変遷してきているのかを検証する必要がある。

\section{6.「理想的植生」管理のための手法 （1）残こしたい草種の明確化}

これまでの個生態や種生物学的な研究や事例的知 見を整理して，場面ごとに「雑草」をリストアップす るとともに，種特性を生かして利用できる植物種を明 らかにする。例えば植物の種特性として，1）作物と 養分や水の競合があるが光競合はない，2）土壤の被 覆効果がある (土潩の飛散・流亡防止効果)，3）土 壤の肥沃度維持効果がある (空中窒素固定)，4）管 理法によって害はあるが，プラス効果が大きいと考え られる，5）管理方法により実質害作用がないと考え られる，6）絶滅が危惧される，7）景観形成に優れ ているなどの種を選定する。具体的には，小型越年 
第 1 表 樹園地における主要雑草の出現傾向とその特徵

\begin{tabular}{|c|c|c|c|c|}
\hline \multicolumn{2}{|r|}{ 指標 } & 笠原のみ出現 & 全国農場のみ出現 & 3 調査で出現 \\
\hline \multirow{2}{*}{\multicolumn{2}{|c|}{$\begin{array}{l}\text { 科数 } \\
\text { 草種数 }\end{array}$}} & 15 & 28 & 18 \\
\hline & & 22 & 94 & 41 \\
\hline \multirow{3}{*}{ 生活型 } & 一年生 (種数) & 10 & 59 & 17 \\
\hline & 多年生 (種数) & 12 & 35 & 24 \\
\hline & 一年生草種率 (\%) & 45.5 & 62.8 & 41.5 \\
\hline \multirow{2}{*}{ 帰化草種 } & 種数 & 2 & 44 & 8 \\
\hline & 帰化草種率 (\%) & 9.1 & 46.8 & 19.5 \\
\hline \multirow{3}{*}{ 草高 } & 低い(種数) & 12 & 31 & 15 \\
\hline & 高い (種数) & 10 & 63 & 26 \\
\hline & 小型草種割合 (\%) & 54.5 & 33.0 & 36.6 \\
\hline \multirow{3}{*}{ 美観 } & 良い(種数) & 8 & 21 & 12 \\
\hline & 悪い (種数) & 14 & 73 & 29 \\
\hline & 良美観種割合 (\%) & 36.4 & 22.3 & 29.3 \\
\hline \multirow{4}{*}{$\begin{array}{c}\text { パラコート } \\
\text { 感受性 }\end{array}$} & 高 (種数) & 14 & 60 & 11 \\
\hline & 中 (種数) & 4 & 26 & 15 \\
\hline & 低(種数) & 4 & 8 & 15 \\
\hline & 高感受性種割合 (\%) & 63.6 & 63.8 & 26.8 \\
\hline \multirow{4}{*}{$\begin{array}{c}\text { グリホサート } \\
\text { 感受性 }\end{array}$} & 高 (種数) & 19 & 81 & 29 \\
\hline & 中 (種数) & 3 & 11 & 10 \\
\hline & 低 (種数) & 0 & 2 & 2 \\
\hline & 高感受性種割合 (\%) & 86.4 & 86.2 & 70.7 \\
\hline \multirow{2}{*}{$\begin{array}{c}\text { 小型かつ } \\
\text { 美観が良い } \\
\text { 草種 }\end{array}$} & 種数 & 8 & 18 & 9 \\
\hline & 割合 (\%) & 36.4 & 19.1 & 22.0 \\
\hline
\end{tabular}

調査結果は第 1 図参照のこと

生草種（スズメノカタビラ, ハコベ, イヌナズナ, オ オイヌノフグリ，ハコベ，ホトケノザ)，匍匐植物（カ キドウシ，チドメグサ，ヘビイチゴ)，小型多年生植 物（カタバミ，スミレ，ジシバリ，スギナ), エロー ジョン防止効果のある草種（ノシバ，ギョウギシバ), 小型一年生植物（スベリヒユ，コニシキソウ，トキワ ハゼ，シロツメクサ，サギソウ，サクラソウ）などが 考えられる。

また, 雑草は, 作物・雑草の相互関係をとらえ, 生態系のバランスを考慮した生態的管理が必要であ る。果樹をはじめとする栽培植物（作物）と雑草間 および植物種間の相互関係は，種数が非常に多く， これらを合理的にとらえる手法が確立していないのが 現状である。根本ら ${ }^{10)}$ は農耕地周辺に自生する小型 植物の被覆による雑草の抑制効果について報告して いるが，こうした植物種の特性を生かした植生維持
のための研究は今後の重要な課題である。とくに，人 里域から農耕地にいたる農耕地周辺の緑地および樹 園地は他の農耕地に比べ土壤擋乱が少なく, 外来植 物の侵入や植生遷移が起こりやすいことから, 植物 種間競合についての解析が緊要なテーマである。

\section{（2）植生の管理技術}

これまでは「雑草ではない植物種」優占の植生（理 想的植生) へ誘導するという考え方で雑草防除が行 われてこなかったが，これからは緑地においても場面 ごとの雑草のみを防除する植生管理技術の開発が望 まれる。例えば樹園地, 農耕地周辺で防除が必要な 草種の特性として，1）大型植物で養分・光・水分 の競合が甚だしい，2）植物種子が風散布で裸地への 繁殖戦略が優れている，3）既存の防除法では防除が 困難である，4）除草剂抵抗性バイオタイプの報告例 がある，5）戦後に帰化した，6）多くの除草剂に感 
受性が低い，7）作業上の支障がある，8）人間に危 害をおよぼす可能性がある，などが挙げられる。具体 的には, イネ科のイヌビエ, チガヤ, アキノエノコロ グサ, メヒシバ, アキメヒシバ, オヒシバ, キク科の セイタカアワダチソウ, オオアレチノギク, ヒメムカ ショモギ，ホウキギク，ブタクサ，大型一年生草種 (イヌビユ, アオビユ, シロザ, エノキグサ, メマツヨ イグサ), 多年生大型草種 (スイバ, ギシギシ), 牧 草種からの逸出帰化植物（ホソムギ, ナガハグサ, シ バムギ，ネズミムギ，イヌムギ，オオアワダチソウ，レ ッドクローバ), つる性植物（ヤブガラシ，ガガイモ， クズ, ヒルガオ), 帰化植物 (イチビ, アメリカネナ シカズラ, イヌホウズキ, オニノゲシ) などが対象植 物と考えられる。

耕耘や刈払いは古くから行われてきた雑草管理方 法であるが，耕耘は現存植生を大きく変化させると ともに裸地化にともなういろいろな生態的な問題があ る。刚払いは現存植生を徐々に変化させることがで きるが，耕耘と同様に極めて多労であり，機械の場 合にも多くのエネルギーを消費する。除草剂は植物種 によって感受性が異なり, 使用する薬量により特定 の草種が優占化する。例えば，非選択性茥葉処理除 草剤を樹園地で連用した場合, パラコート・ジクワ ット液剂ではアレチノギク類, ヒメジョン類, メヒシ バが優占化し，グリホサート系除草剤ではメマツヨイ グサ，メヒシバ，エノキグサ，スギナが優占化し，グ ルホシネート液剤ではイヌムギ，メヒシバ，イタリア

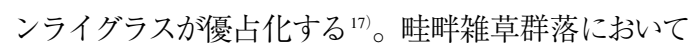
抑草剂を連用した場合も, 種組成に及ぼす影響は除 草剂に比べ小さものの多年生の減少や感受性の低 い特定草種が増加することか報告 ${ }^{16)}$ されている。ま た，近年カバープランツと称して外来植物種を用い て, 土壤被覆を目的とした植物種の単一群落化をめ ざす農法や作付け体系の中で休閑期に外来植物（へ アリーベッチやエンバクなど）を作付ける実践例が報 告されている。古来レンゲでの実践結果に見られるよ うに, 作物以外の植物種で単一群落化することの環 境リスクを考えるとこれらの農法のもつ限界性はすで に明白である。

このように理想的植生への誘導には, 耕種的防除 に化学的防除も含めて, 20 世紀に開発された防除技 術のすべてを組み合わせて管理する方法を検討する必
要がある。例えば，「生存させる植物種」に感受性の 低い選択性除草剂を組み合わせた体系処理も有効な 手段の一つである ${ }^{13)}$ 。多様な植物種の混合群落のよ り安定的な植生を, できるだけ省力省資源で, 管理 する技術の確立が求められている。

\section{引用文献}

1) 萩本宏 2001. 雑草の定義と雑草学の役割. 雑草研究 46 (1), 56-59.

2) Hayashi, I. (1977) Secondary succession of herbaceous communities in Japan. Japanese Journal of Ecology 27, 191-200.

3）飯島和子 - 佐合隆一 2005. 埋立地の二次遷移過程に 出現した優占種の特性. 杂隹草研究 50(3), 184-192.

4）飯島和子 2006. 東京湾沿岸の埋立地における植物群落 の二次遷移とその構成種の生態生理学的研究. 東京農工 大学大学院博士論文 pp6-65.

5）飯島和子・佐合隆一 2006. 東京湾岸浚渫埋立地におけ るクロマツ群落とトウネズミモチ群落の出現要因. 日本 緑化工学会誌 31 (3), 373-379.

6）伊藤貴庸 - 中山祐一郎 - 山口裕文 1999. 伝統的畦畔と 基盤整備畦畔における植生構造とその変遷過程. 雑草研 究 44 (4), 329-340.

7）笠原安夫 1972. 「日本雑草図説」養賢堂, 東京.

8）加用信文 1996. 「農法史序説」御茶八水書房, 東京, pp.43-82.

9）前中久行 2001.ランドスケープの立場からみた市街地環 境と “雑草”. 雑草研究 46 (1), 48-55.

10）根本正之. 大塚俊之 1998. 農耕地周辺に自生する小型 植物の被覆による雑草抑制効果. 杂隹草研究 43(1), 26-34.

11）沼田真 1977. 「植物生態学講座 4 群落の遷移とその機 構」朝倉書店, 東京, pp. 127-130.

12）佐合隆一・中谷英夫2005. 樹園地における雑草の再定 義. 杂隹草研究 50(別), 184-185.

13）佐合隆一・西島美樹 2006. 除草剂の体系処理による緑 地の植生管理. 杂隹草研究 51 (別), 224-225.

14）塩谷哲夫 2000. 畑地及び樹園地における雑草の生態調 查. 平成 8 年度 平成 10 年度科学研究費補助金研究成 果報告書. 1-193.

15）竹下孝史 2005. わが国に扒ける除草剤使用の推移3. 芝 関係, 水田畦畔 - 休耕田, 林地 - 緑地管理関係除草剂 について. 雑草研究 50 (2), 106-118.

16）土田邦夫 · 山木義賢 - 竹下孝史 - 則武晃二 2000. 畦 畔雑草群落の種組成に及ぼす抑草剂連年使用の影響. 雑 草研究 45(別), 104-105.

17）上原史 · 榎吉寿夫 · 本田達夫 · 門田源一 - 佐合隆一 2000. 樹園地に扔ける非選択性茎葉処理除草剤の連用に よる雑草草種の変化. 杂隹草研究 45(別), 166-167. 